\title{
Clear and Present Danger: Planning and New Venture Survival amid Political and Civil Violence
}

\section{Citation}

Hiatt, Shon R., and Wesley Sine. "Clear and Present Danger: Planning and New Venture Survival amid Political and Civil Violence." Strategic Management Journal (forthcoming).

\section{Permanent link}

http://nrs.harvard.edu/urn-3:HUL.InstRepos:12534949

\section{Terms of Use}

This article was downloaded from Harvard University's DASH repository, and is made available under the terms and conditions applicable to Open Access Policy Articles, as set forth at http:// nrs.harvard.edu/urn-3:HUL.InstRepos:dash.current.terms-of-use\#OAP

\section{Share Your Story}

The Harvard community has made this article openly available.

Please share how this access benefits you. Submit a story.

\section{Accessibility}




\title{
CLEAR AND PRESENT DANGER: PLANNING AND NEW VENTURE SURVIVAL AMID POLITICAL AND CIVIL VIOLENCE
}

\begin{abstract}
Many entrepreneurs in developing economies face unstable environments due to violence and civil unrest. Yet, we know very little about how environments characterized by high levels of political and civil violence affect new venture processes and survival. Moreover, it is unclear whether standard theories about organizational strategy, such as planning, hold true in such environments. We explore these issues using a sample of 730 new ventures in Colombia from 1997 to 2001. We find that political and civil violence decreases firm survival, increases the benefits of incremental (operational) planning, and decreases the benefits of comprehensive (strategic) planning.
\end{abstract}

Shon Hiatt

Harvard Business School

Wesley Sine

Cornell University

Forthcoming in Strategic Management Journal 


\section{INTRODUCTION}

The relationship between the institutional environment and organizational outcomes is of growing interest to strategy and entrepreneurship researchers (Hoskisson et al., 2000; Ingram and Silverman, 2002; Peng et al., 2009; Hiatt and Park, 2013). For example, scholars have examined the effects of state policies (Dobbin and Dowd, 1997; Fligstein, 2001; Henisz and Delios, 2001; Garcia-Canal and Guillen, 2008; Vaaler, 2008), culture (Hiatt, Sine and Tolbert, 2009), certification systems (Rao, 1994; Sine, David, and Mitsuhashi, 2007; Lee, 2009), and economic environments (Meyer, et al., 2009) on organizational performance, personnel strategies, alliances, and foreign-entry decisions. Despite this surge of attention, most studies in strategy and entrepreneurship assume stable, predictable environments in which new firms are founded (Spicer, McDermott, and Kogut 2000). Violence and unrest and the lack thereof are vital components of the institutional environment. Yet, many states around the world suffer from political and civil violence. In such contexts, we ask: How do high levels of violence affect new venture survival and moderate key entrepreneurial processes such as business planning-a fundamental strategic activity in which entrepreneurs engage (Hills, 1988)? This study contributes to the institutionally informed view of strategy by investigating how contexts characterized by high levels of violence affect new venture survival by creating uncertain environments that alter entrepreneurial perception of risk, disrupt resource flows and organizational routines, and thereby moderate the effects of incremental (day-to-day operational) and comprehensive (forward-looking strategic) planning.

\section{THEORY AND HYPOTHESES}

\section{Violence, uncertainty, and new venture survival}

The institutionally informed view of strategy and entrepreneurship highlights how formal (i.e., regulations, policies) and informal (i.e., norms, culture) constraints can shape strategic 
decision making and performance (Peng and Heath, 1996; Peng and Luo, 2000; Davis, 2005;

Webb et al., 2009; Tolbert, David, and Sine, 2011). While this view has broadened strategy and entrepreneurship research beyond individual, industry- and resource-based factors by emphasizing the heterogeneous nature of institutions, research in this area has generally overlooked violence and civil unrest even though these reflect key aspects of the institutional environment (Hirsch and Lounsbury, 1997; Zahra and Wright, 2011; but see Honig, 2001).

Environments characterized by high levels of political and civil violence are inherently unstable, difficult to predict, and uncertain (Bonanate, 1979). It is precisely the inability to anticipate where and against whom the violence will occur that causes high levels of uncertainty. However, unlike uncertainty described in traditional strategy literature (Miles and Snow, 1978; Ireland et al., 1987; Sawyerr, 1993), the effect of uncertainty created from violence is far greater in magnitude because it includes an additional, yet heavily weighted dimension: the individual's physical security (Bonanate, 1979). When violence-induced uncertainty is high, it instills fear and concern for personal safety, which can affect rational economic decision making (Friedland and Merari, 1985; Porac and Shapira, 2001). Consequently, violence can lead founders, investors, buyers, and suppliers to make overly pessimistic risk estimates and more risk-averse choices, thereby creating erratic and at times irrational behavior (Lerner et al., 2003), contributing to new venture failure.

For example, in our study, an entrepreneur from Bogotá recalled a sales visit to a distant neighborhood: as she pulled up to a red light, two men smashed the window of the car in front of her and kidnapped the driver, eventually holding him for ransom. After this experience, she reduced the scope and size of her venture and left her office and its environs as rarely as 
possible1. Because few of her existing and potential clients had telephones, her actions resulted in a decline in business and lost future opportunities. In a second example, an entrepreneur in Cali explained that political and civil unrest (either FARC or paramilitary activity) made him very apprehensive about whom he interacted with in business transactions, alliances, and social activities. Because it was difficult to know whether someone had ties to a paramilitary group, had been member of a labor union, or was sympathetic with guerrilla groups, he avoided contact with people he didn’t know well, including those who owned businesses in the same geographical area. "I was very careful about whom I had a cup of coffee with. I was cordial to my neighbors, but avoided doing things with them because I didn't know their past. They could be friends with the paras, the guerrillas or drug traffickers.” Due to the high rate of violence, this entrepreneur avoided creating new business and social relationships with people outside of his neighborhood.

In a final example, a mechanic in Medellín remarked that as erratic violence in Medellín flared, customers were more likely to stay home and to forgo servicing their cars. Not only did violence decrease customer demand, it also made it difficult for the entrepreneur to predict when customers would visit his shop. Thus, he could not rely on past customer patterns to staff his shop because customer behavior was no longer predictable; customers would come when the shop was closed or understaffed or wouldn't come when it was open and fully staffed. This resulted in operating inefficiencies, poor customer service, and near insolvency. Similarly, several entrepreneurs remarked that during periods of violence, it was difficult to attract funding and credit because investors and creditors felt that the environment was too risky.

\footnotetext{
${ }^{1}$ Despite the fact that the likelihood of being severely injured in a car accident was much greater than being kidnapped, it was being a victim of violence and kidnapping that shaped her decision to reduce the geographical reach of her business.
} 
In sum, political and civil violence creates high uncertainty about where and against whom physical harm will occur, thereby affecting the willingness of entrepreneurs to take risks and engage in important entrepreneurial tasks as well as fostering erratic behavior among suppliers, customers, and creditors, making it difficult for new ventures to operate. Given that new ventures often have few slack resources to shield them from abrupt changes in supplier, customer, and creditor behavior than established firms (Phillips, 2002; Aldrich and Ruef, 2006), such disruptions are likely to lead to venture failure.

Hypothesis 1: Political and civil violence will negatively affect the likelihood of survival of entrepreneurial ventures.

\section{New venture planning and political and civil violence}

Organizations often cope with uncertainty by turning to planning processes (Armstrong, 1982; Bracker and Pearson, 1986; Eisenhardt, 1989). We focus on two, non-mutually exclusive planning processes: incremental and comprehensive. Incremental planning is concerned with reacting to environmental issues at the operational level. It can increase new venture survival by helping firms (1) improve operational performance through regular evaluations of current processes (Mitzberg, 1994); (2) make quicker decisions regarding their day-to-day operations by revealing where they should place their attention when operational variance occurs (Shrader, Mulford, and Blackburn, 1989); and (3) recognize the relationships between resource flows and firm actions, thereby preventing potential bottlenecks and overproduction (Delmar and Shane, 2003). In sum, we posit that new firms that engage in incremental planning will increase their probability of survival because such planning helps firms increase operational efficiency, adapt quickly to changes in the environment, and reduce costly mistakes.

Hypothesis 2: Higher levels of incremental planning will positively affect the likelihood of survival of entrepreneurial ventures. 
Comprehensive planning entails proactively planning at the strategic level (Bracker and Pearson, 1986; Bracker et al., 1988). Comprehensive planning is future-oriented and often focused on making significant changes based on assumptions about trends and organizational needs. The comprehensive planning process is characterized by exhaustiveness and inclusiveness when searching for information, analyzing it, and making detailed business plans. We posit that comprehensive planning can increase firm margins and cost savings by helping ventures to (1) set a clear vision for the future and establish concrete objectives and action items, thereby establishing important firm processes (Shrader et al., 1989); (2) evaluate the feasibility of engaging in a particular action, thus enabling ventures to avoid costly errors (Bracker and Pearson, 1986); and (3) improve long-term coordination among functional areas, thereby increasing future organizational efficiency (Castrogiovanni, 1996). However, because comprehensive planning requires greater resources to implement than incremental planning and creates firm processes that can foment organizational inertia and make adaptation difficult, the benefits derived from comprehensive planning are likely to decline at a marginal rate among new ventures as they engage in greater comprehensive planning. Hence we posit:

Hypothesis 3: Higher levels of comprehensive planning will positively affect the likelihood of survival of entrepreneurial ventures, albeit at a marginally declining rate.

Because both incremental and comprehensive planning make basic assumptions about the stability and predictability of the environment and are used by organizations to adjust to environmental uncertainty (Castrogiovanni, 1996), their effects are likely to change under conditions of high levels of violence. A fundamental assumption underlying the benefits of incremental planning is that as environments change, incremental planning helps ventures respond to such changes more quickly and effectively. Consequently, as market environments become more unpredictable and turbulent, such planning processes would help entrepreneurs react and adjust daily production, supply, and sales accordingly. For example, Luis, an 
entrepreneur working in the southern barrios of Bogotá, stated that he focused heavily on incremental planning by daily monitoring his production and sales and actively adjusting his prices, inventory, and product selection when violence between guerrillas and paramilitaries was high. This allowed his leather-goods shop to quickly adapt to a changing environment and survive when others failed. Given that incremental planning can lead to greater venture agility in uncertain and threatening environments, we argue that the effects of incremental planning on new venture survival will be stronger in such environments.

Hypothesis 4: Incremental planning will contribute more to business survival as civil and political violence increases.

Entrepreneurs also use comprehensive planning to reduce environmental uncertainty (Shrader et al., 1989). Comprehensive planning differs from incremental planning in that instead of concentrating on the present, it focuses on the future and helps organizations make significant changes over time that improve their long-term capabilities. The success of long-range comprehensive planning is linked to the predictability of the environment because comprehensive plans are based on the entrepreneur's best prediction about future market needs and growth opportunities (Mintzberg, 1994). However, in environments with extreme levels of uncertainty such as those plagued by civil and political violence, comprehensive planning may become less beneficial or even harmful as violence induces erratic behavior among customers, suppliers, and creditors, making strategic predictions less accurate and leading the venture to invest in building capabilities that are not aligned with future environmental changes.

For example, Maria, an entrepreneur living in a barrio on the outskirts of Cartagena, Colombia, an area with little police presence, decided in 1999 to expand her ice cream business into a small restaurant; she created a long-term plan and began to implement it by paying a deposit for and taking delivery of the necessary equipment. Unfortunately, at the same time, the violence abruptly changed local habits-people spent less time out of their houses, which meant 
they were less likely to frequent her business and purchase ice cream and other types of food.

Within six months she fell behind in her payments and lost her equipment, her savings, and her business. In sum, we argue that environments with high levels of violence and accompanying uncertainty will decrease the benefit of comprehensive planning to new venture survival.

Hypothesis 5: Comprehensive planning will contribute less to business survival as civil and political violence increases.

\section{METHODS AND ANALYSIS}

We examined the impact of violence, planning, and their interaction on 770 entrepreneurial ventures in Colombia from 1997 to 2001. (We dropped 40 firms because of missing data, leaving 730 for analysis.) These small and medium-sized ventures were located in Colombia’s five largest cities: Bogotá, Medellín, Cartagena, Cali, and Barranquilla. ${ }^{2}$ During this study’s period, Colombians faced intense fighting between leftist political guerrillas and drugcartel-funded paramilitary forces. For the three decades prior to 2004, homicide had been the chief cause of mortality for men between the ages of 16 and 34 in Colombia's principal cities (Safford and Palacios, 2002). By 2000, Colombia averaged 30,000 murders a year (about 1,000 percent higher than U.S. homicide rates), 75 political assassinations a week, and 10 kidnappings a day (Dudley, 2004). One entrepreneur from the city of Medellín described the particularly brutal period between 1999 and 2001:

There were weeks when 70 people died each day. Violence and theft were common. The government had no control. Sometimes when you caught a bus, five men would grab you and take everything out of your pockets. You couldn't defend yourself, even if you had a gun. Every day they killed a bus driver. Buses stopped going to some neighborhoods, cutting those people off from the rest of the city.

\footnotetext{
2 Of these enterprises 19.9 percent were located in Bogotá, 19.8 percent in Medellín, 13.8 percent in Cartagena, 25 percent in Cali, and 21.6 percent in Barranquilla. Of the entrepreneurs, 47.5 percent were female, and 52.5 percent were male; their formal education ranged from none to a four-year university degree. Between 1997 and $1998,29.7$ percent of the 770 firms failed. Of those that survived, 30.6 percent failed between 1998 and 2001, leaving 40 percent of the original 770 firms surviving in 2001. While single respondent bias may have occurred in some cases, the authors tried to assuage this concern by interviewing multiple members of each venture.
} 
In sum, the failure of the state to ensure personal safety, maintain order, and control unrest had created highly uncertain environments for Colombian entrepreneurs, but this violence varied in intensity from region to region and from year to year. Colombia thus presents a unique and valuable context in which to study how political and civil violence, business planning, and their interaction affect entrepreneurial survival.

\section{Data sources}

We obtained data from Fundación Corona, a large nonprofit that offers training and loans to small entrepreneurial start-up firms in Colombia. Corona administered three longitudinal surveys to start-up owners (in 1997, 1998, and 2001) that had used their services as well as to start-up owners from a matched sample of ventures that were randomly selected within the same region (Cabal et al., 1996, 1997). In order to identify ventures both in the formal and informal sectors, research teams knocked on every door within randomly selected neighborhoods (located in the same economic zones as the initial sample) asking residents if they had recently started a venture, and if so, inviting them to participate in the survey. We took multiple trips to Colombia to check the robustness of the data and to gather additional qualitative and quantitative data. We supplemented the survey data with economic data (described below) that we obtained from Colombia’s National Administrative Department of Statistics and from the Ministry of Defense.

\section{Dependent and independent variables}

Our dependent variable is firm survival, and our independent variables are political and civil violence and incremental and comprehensive business planning. Because homicides and kidnappings are prominent features of political and civil violence in Colombia and many other emerging markets, we constructed our measure of violence using a factor analysis postestimation of two measures: annual regional homicides and annual regional extortive 
kidnappings. ${ }^{3}$ We operationalized incremental planning using the product of two variables. The

first was a scale measure that captured the extent to which the entrepreneur monitored, updated, and compared production and sales activities to changes in the environment. The second was a binary variable that captured the extent to which an entrepreneur went into detail when appraising production and sales activities. We measured comprehensive planning using a series of nine questions that addressed the extent to which the entrepreneur made detailed future plans. We aggregated these questions into a single item using post-factor estimation to create a scale representing the extent to which an entrepreneur engages in comprehensive planning. ${ }^{4}$ Finally, we created a squared term for comprehensive planning to capture any declining benefits.

\section{Control variables}

At the founder level, we controlled for the entrepreneur's years of prior work experience and the entrepreneur's age, as well as whether the entrepreneur owns another business, whether the entrepreneur has a secondary job, whether the entrepreneur currently studies and the entrepreneur's gender using binary variables (1=yes, 1=male) (Gimeno et al., 1997). Education was operationalized using an ordinal scale that reported the entrepreneur's highest attained education level.

At the organization level we controlled for the number of temporary employees, nonpaid employees, the number of apprentices, and whether the principal method of employee search was

\footnotetext{
${ }^{3}$ Varying over time and geography, the two variables loaded onto a single factor with an eigenvalue of 1.10. A Cronbach's alpha test reported a scale reliability coefficient of 0.80 . The item's values ranged from -1.133 to 2.509, with a mean of around zero. The five cities in the study are located in separate regions of Colombia, and each city accounts for well over 70 percent of its region's population; thus political and civil violence in a given region largely represents that of its largest city.

${ }^{4}$ We conducted an exploratory factor analysis on the comprehensive planning variables related to market growth, equipment purchases, raw-material purchases, new product development and introduction, management training, location strategies, firm expansion, debt financing and payments, and customer credit to verify that they did in fact represent the same underlying planning construct. The items loaded maximally and uniquely onto a single factor, which had an eigenvalue of 1.863 and accounted for 93.1 percent of the variation. Only the first factor yielded eigenvalues greater than one. A Cronbach's alpha test of the nine items reported an acceptable scale reliability coefficient of 0.702 (Nunnally, 1978).
} 
through family and friends (recruitment practices) $(1=y e s)$. We also controlled for whether the organization offered product/service guarantees with after-sales/service support. We controlled for organizational age in years and organizational size in terms of the number of actual employees. Additionally, we controlled for 10 industry types using sector dummy identifiers (industry controls) (Mizruchi et al., 2006). At the environment level, we also controlled for the percentage of regional unemployment, the regional gross domestic product per capita, regional inflation using the regional consumer price index, and regional exports per capita.

\section{Analysis}

Although we know the year in which failed ventures ceased operation, the exact day of failure was missing for 80 percent of the firms. We therefore conducted a discrete-time history analysis to test our theory using a complementary log-log specification, which accounts for both the continuous nature of the actual exit process and the discrete nature of the data (Allison, 1982). These models are of the form: $\log \left[-\log \left(1-p_{i t l t 2}\right)\right]=\alpha+\beta X_{i t 1}$, where $p_{i t l t 2}$ is the probability that firm $i$ will survive during the period $t_{1}$ to $t_{2}, X_{i t l}$ is a vector of covariates associated with firm $i$ at time $t_{1}, \beta$ is its corresponding parameter vector, and $\alpha$ is a constant. ${ }^{5}$ As a robustness test, we also conducted a logistic regression on the same model and produced similar results.

---Insert Table 1 and Table 2 about here---

\section{Results}

Descriptive statistics and bivariate correlations appear in Table 1. The results of the discrete-time logistic model of firm survival appear in Table 2. The results support hypotheses 1 , 3, 4, and 5, but not hypothesis 2. Hypothesis 1 theorized a relationship between violence and venture failure. We find that an increase in violence of one standard deviation increased the

\footnotetext{
${ }^{5}$ Some of our variables were highly correlated (such as planning and planning squared, and GDP and violence), which can inflate standard errors and make regression coefficients unstable. We used a Gram-Schmidt procedure to partial out the common variance between the highly correlated variables (Sine, et al., 2005). We then tested for multicollinearity and found that all variance-inflation factors were less than 3.71 .
} 
likelihood of failure by 10 percent. However, the results indicate that incremental planning does not differ significantly between ventures that survived and ventures that did not (hypothesis 2).

We tested for curvilinear effects of incremental planning, but they were not statistically significant. This suggests that generally, the cost of frequently scanning and updating organizational routines is greater than its benefits. As predicted by hypothesis 3 , we find that an increase in comprehensive planning of one standard deviation significantly increased firm survival by 2 percent; however, an increase in comprehensive planning of two standard deviations reduced firm survival by 3 percent, suggesting marginally declining benefits.

We also find that violence moderates the effects of planning, as suggested by hypothesis 4; a standard deviation increase in violence augmented the effects of incremental planning on firm survival by 4 percent. Similarly, we find that a one-standard deviation increase in violence decreased the effects of long-term planning on firm survival by 12 percent (hypothesis 5). In Model 8, the interaction between comprehensive planning squared and violence was not significant. Figure 1 compares comprehensive and incremental planning in environments of high political and civil violence.

---Insert Figure 1 about here---

It is possible that planning is an indicator of unobserved venture capabilities. We believe this is unlikely because all the ventures in this sample were young and had little time to create organizational capabilities. ${ }^{6}$ Nevertheless, if planning is merely an indicator of unobserved venture capabilities, these results suggest that capabilities that may be highly predictive of

\footnotetext{
${ }^{6}$ In order to control for potential unobserved venture capabilities linked to organizational experience, we included venture age. As a further robustness test of these results, we ran the same model using data from the first survey to predict survival one year later. The results did not differ significantly from model 7 . Because all the ventures in this analysis were fairly young and extremely small, capabilities were more likely to be linked to the founder's human capital rather than to established organizational routines. Thus, we included controls for entrepreneurial experience, education, and age, and resources such as firm size, and paid and unpaid employees.
} 
success in stable environments are predictive of failure in unstable environments characterized by high levels of violence, an interesting finding in and of itself.

\section{DISCUSSION}

In this paper, we showed that high levels of violence affect new venture survival in two ways. First, by fostering uncertainty and erratic behavior among entrepreneurs, suppliers, customers, and creditors, environments characterized by relatively high levels of violence disrupt resource flows and vital organizational routines, thereby increasing firm failure. It was not political and civil violence per se that decreased the survival rates of entrepreneurial firms: less than 0.1 percent of the firms in our sample were direct targets of organized violence. Instead, we argue that the impact of violence on venture survival was due to how such environments affect risk perception and decision processes by entrepreneurs and their constituents. These effects are substantial. Our results suggest that a one standard deviation increase in violence translates into the failure of an additional 120,000 Colombian new ventures, triggering a loss of over 257,000 jobs. Second, violence and the resulting uncertainty and environmental change moderate the effects of entrepreneurial planning by increasing the adaptive benefits of day-to-day incremental planning and decreasing the benefits of forward-looking comprehensive planning, thereby affecting new venture longevity. The differential effects of these two types of planning are impressive. If entrepreneurs in violent regions of Colombia increased incremental planning by one standard deviation, 6000 additional ventures would be saved; in contrast, an increase of one standard deviation from the mean in comprehensive planning would translate into 4800 more venture failures. Whereas incremental planning has no significant impact on venture mortality in stable environments, it can be an effective strategy for mitigating the effects of high levels of violence. 
Our study contributes to entrepreneurship and strategy research in several ways. First, it builds upon the institutionally informed view of strategy by demonstrating how prior theory on business planning does not hold in areas characterized by high violence (Peng et al., 2009). Previous studies assert that planning is beneficial in uncertain environments because it provides firms with valuable information, contingencies, and an accessible set of actions to readily implement (Armstrong, 1982). While we find that this proposition is supported for incremental planning, our results indicate that high levels of comprehensive planning in environments of high civil and political violence have a net negative effect on new venture survival.

Second, prior work has been deeply divided on the utility of business planning for the survival of start-up firms (Delmar and Shane, 2003; Pearce, Freeman, and Robinson, 1987). Much of this conflict may be due to prior studies failing to differentiate between various types of new venture planning, treating it as a single construct, and failing to take into account the institutional environment. We offer a potential explanation for the discrepancies between past empirical studies by distinguishing incremental (day-to-day operational) from comprehensive (forward-looking strategic) planning and theorizing and empirically testing the differential effects of these planning processes on new venture survival rates in varying institutional contexts.

This study is particularly relevant to entrepreneurs and organizations promoting new venture planning in countries experiencing violence and civil unrest such as war, civil war, or piracy. Currently, prospective entrepreneurs are taught the importance of business planning by both universities and non-governmental organizations that offer entrepreneurial training. Qualitative interviews at non-governmental organizations and universities in Colombia suggest that these organizations train prospective Colombian entrepreneurs to engage in comprehensive planning. Our empirical data support this finding: Entrepreneurs who had received training were 
more likely to engage in strategic planning by 1.58 times $(\mathrm{p}<.001)$. In such contexts where violence is high, these training programs may actually increase the likelihood of new venture failure.

Fruitful avenues for future research include exploring other types of strategic actions that entrepreneurs and managers can take to reduce the negative impact of political and civil unrest. For instance, how would ties to powerful coercive actors such as the military in countries with weak formal institutions mitigate the negative effects of such contexts? Finally, while this study demonstrates the short-term benefit of modifying planning processes according to the level of violence, it also begs the question: What are the long-term implications of such survival strategies on innovation and economic productivity at the organizational and societal levels? Finding answers to these questions will help us better understand the consequences of political and civil unrest on national economies.

ACKNOWLEDGEMENTS: The authors thank senior editor Will Mitchell and the anonymous reviewers for their guidance and Mathew Allen, Ariel Avgar, Glenn Dowell, María Lorena Gutiérrez Botero, Elizabeth Hiatt, Brandon Lee, Sangchan Park, Joseph Price, William Sonnenstuhl, and Pamela Tolbert for helpful comments on earlier drafts of the paper. We also thank Jorge Hernán Cárdenes and Miguel Cabal for their support; Jorge Bermejo de Arco, Leonel Arce Silva, Esteban Sanchez Ramirez, Leonardo Villarraga Sanchez and William Fonseca Casa for their assistance in surveying entrepreneurs; and participants of the CornellMcGill Institutions and Entrepreneurship and the TCU Entrepreneurship in Emerging Markets conferences for their helpful criticism. We acknowledge financial support from the Harvard Business School Division of Research, the Cornell ILR School, the Mario Einaudi Center for International Studies, and the Johnson Graduate School of Management.

\section{REFERENCES}

Aldrich HE, Ruef M. 2006. Organizations Evolving. Sage Publications: Thousand Oaks, CA. Allison P. 1982. Discrete-time methods for the analysis of event histories. Sociology Methodology 13:61-98.

Armstrong JS. 1982. The value of formal planning for strategic decisions: review of empirical research. Strategic Management Journal 3(3): 197-211.

Bonanate L. 1979. Some unanticipated consequences of terrorism. Journal of Peace Research 16(3): 197-211.

Bracker JS, Keats BW, Pearson JN. 1988. Planning and financial performance among small firms in a growth industry. Strategic Management Journal 9(6): 591-603.

Bracker JS, Pearson JN. 1986. Planning and financial performance of small, mature firms. Strategic Management Journal 7(6): 503-522. 
Cabal M, Hidalgo M, Monroy P. 1996. Diseño de un Sistema de Evaluación de Impacto de los Servicios de Apoyo a las Microempresas en Colombia. Cede Uniandes: Bogotá, Colombia.

Cabal M, Hidalgo M, Monroy P. Garcia, L. 1997. Caracterización estática y dinámica de las microempresas beneficiarias y no beneficiarias del plan nacional de la microempresa. Departamento Nacional de Planeación-Fundación Corona: Bogotá, Colombia.

Castrogiovanni GJ. 1996. Pre-startup planning and the survival of new small businesses: theoretical linkages. Journal of Management 22(6): 801-822.

Davis G. 2005. Firms and environments. In Handbook of Economic Sociology, 2nd Edition, Smelser N, Swedberg R (eds). 478-502.

Delmar F, Shane S. 2003. Does business planning facilitate the development of new ventures? Strategic Management Journal 24(12): 1165-1185.

Dobbin F, Dowd T. How policy shapes competition: early railroad foundings in Massachusetts. Administrative Science Quarterly 42: 501-529.

Dudley S. 2004. Walking Ghosts: Murder and Guerrilla Politics in Colombia. Routledge: New York.

Eisenhardt K. 1989. Making fast strategic decisions in high-velocity environments. Academy of Management Journal 32 (3): 543.

Fligstein N. 2001. The architecture of markets: An economic sociology of twenty-first-century capitalist societies. Princeton University Press: Princeton.

Friedland N, Merari A. 1985. The psychological impact of terrorism: a double-edged sword. Political Psychology 6(4): 591-604.

Garcia-Canal E, Guillen M. 2008. Risk and the strategy of foreign location choice in regulated industries. Strategic Management Journal 29: 1097-1115.

Gimeno J, Folta TB, Cooper AC, Woo CY. 1997. Survival of the fittest? Entrepreneurial human capital and the persistence of underperforming firms. Administrative Science Quarterly 42: 750-783.

Hiatt SR, Park S. 2013. Lords of the harvest: Third-party influence and regulatory approval of genetically modified organisms. Academy of Management Journal, forthcoming.

Hiatt SR, Sine WD, Tolbert PS. 2009. From Pabst to Pepsi: the deinstitutionalization of social practices and the creation of entrepreneurial opportunities. Administrative Science Quarterly 54: 635-667.

Hills GE. 1988. Variations in university entrepreneurship education: an empirical study of an evolving field. Journal of Business Venturing 3(2): 109-122.

Hirsch P, Lounsbury M. 1997. Putting the organization back into organization theory: action, change, and the new institutionalism. Journal of Management Inquiry 6:79-88.

Henisz WJ, Delios A. 2001. Uncertainty, imitation, and plant location: Japanese multinational corporations, 1990-1996. Administrative Science Quarterly 46(3): 443-475.

Honig B. 2001. Human capital and structural upheaval: a study of manufacturing firms in the West Bank. Journal of Business Venturing 16(6): 575-594.

Hoskisson RE, Eden L, Lau CM, Wright M. 2000. Strategy in emerging economies. Academy of Management Journal 43(3): 249-267.

Ingram P, Silverman BS. 2002. The new institutionalism in strategic management. Advances in Strategic Management 19:1-32.

Ireland RD, Hitt MA, Bettis RA, Auld de Porras D. 1987. Strategy formulation processes: differences in perceptions of strength and weaknesses indicators and environmental uncertainty by managerial level. Strategic Management Journal 8(5): 469-485.

Lee BH. 2009. The infrastructure of collective action and policy content diffusion in the organic food industry. Academy of Management Journal 52: 1247-1269.

Lerner J, Gonzalez R, Small D, Fischhoff B. 2003. Effects of fear and anger on perceived risks of terrorism: a national field experiment. Psychological Science 14(2): 144-150.

Meyer KE, Estrin S, Bhaumik SK, Peng MW. 2009. Institutions, resources, and entry strategies in emerging economies. Strategic Management Journal 30(1): 61-80.

Miles RE, Snow CC. 1978. Organizational Strategy, Structure, and Process. McGraw-Hill: New York. 
Mintzberg H. 1994. The Rise and Fall of Strategic Planning. Free Press: New York.

Mizruchi M, Stearns L, Marquis C. 2006. The conditional nature of embeddedness: a study of borrowing by large U.S. firms, 1973-1994. American Sociological Review 71: 310- 333.

Nunnally J. 1978. Psychometric Theory. McGraw-Hill: New York.

Pearce J, Freeman E, Robinson R. 1987. The tenuous link between formal strategic planning and financial performance. Academy of Management Review 12(4): 658-676.

Peng MW, Heath PS. 1996. The growth of the firm in planned economies in transition: institutions, organizations, and strategic choice. Academy of Management Review 21(2): 492-528.

Peng MW, Luo Y. 2000. Managerial ties and firm performance in a transition economy: the nature of a micro-macro link. Academy of Management Journal 43(3): 486-501.

Peng MW, Sun SL, Pinkham B, Chen H. 2009. The institution-based view as a third leg for a strategy tripod. Academy of Management Perspectives 23(3): 63-81.

Phillips D. 2002. A genealogical approach to organizational life chances: the parent-progeny transfer among Silicon Valley law firms, 1946-1996. Administrative Science Quarterly 47:474-506.

Porac J, Shapira, Z, 2001. On mind, environment, and Simon's scissors of rational behavior. Journal of Management and Governance 5:206-213.

Rao H. 2004. The social construction of reputation: certification contests, legitimation, and the survival of organizations in the American automobile industry: 1895-1912. Strategic Management Journal 15: 29-44.

Safford F, Palacios M. 2002. Colombia: Fragmented Land, Divided Society. Oxford University Press: New York.

Sawyerr OO. 1993. Environmental uncertainty and environmental scanning activities of Nigerian manufacturing executives: A comparative analysis. Strategic Management Journal 14(4): 287-299.

Shrader CB, Mulford CL, Blackburn VL. 1989. Strategic and operational planning, uncertainty, and performance in small firms. Journal of Small Business Management 27(4): 45-60.

Sine W, David RJ, Mitsuhashi H. 2007. From plan to plant: effects of certification on operational start-up in the emergent independent power sector. Organization Science 18: 578-594.

Sine W, Haveman H, Tolbert P. 2005. Risky business: entrepreneurship in the new independentpower sector. Administrative Science Quarterly 50: 200-232.

Sine W, Kirsch D, Mitsuhashi H. 2006. "Revisiting Burns and Stalker: Formal structure and new venture performance in emerging economic sectors.” Academy of Management Journal 49: 121-132.

Spicer A, McDermott G, Kogut B. 2000. Entrepreneurship and privatization in Central Europe: the tenuous balance between creation and destruction. Academy of Management Review 25(3): 630-649.

Tolbert PS, David R, Sine WD 2011. "Studying choice and change: the intersection of institutional theory and entrepreneurship research.” Organization Science: 1359-1367

Vaaler PM. 2008. How do MNCs vote in developing country elections? Academy of Management Journal 51(1): 21-43.

Webb JW, Tihanyi L, Ireland RD, Sirmon DG. 2009. You say illegal, I say legitimate: entrepreneurship in the informal economy. Academy of Management Review 34(3): 492-510.

Zahra S, Wright M. 2011. Entrepreneurship's next act. Academy of Management Perspectives 25:67-83. 
TABLE 1

Descriptive Statistics and Bivariate Correlations

\begin{tabular}{|c|c|c|c|c|c|c|c|c|c|c|c|c|}
\hline & Variables & Mean & St. Dev. & 1 & 2 & 3 & 4 & 5 & 6 & 7 & 8 & 9 \\
\hline 1 & New venture survival & 0.584 & 0.493 & 1 & & & & & & & & \\
\hline 2 & Political and civil violence & -0.090 & 1.026 & -0.068 & 1 & & & & & & & \\
\hline 3 & Incremental planning & 2.618 & 4.616 & -0.036 & -0.003 & 1 & & & & & & \\
\hline 4 & Comprehensive planning & -0.066 & 1.174 & 0.086 & -0.253 & 0.102 & 1 & & & & & \\
\hline 5 & Entrepreneur's gender (male) & 0.381 & 0.486 & -0.050 & 0.224 & 0.017 & -0.115 & 1 & & & & \\
\hline 6 & $\begin{array}{l}\text { Entrepreneur's education level } \\
\text { Entrepreneur's prior years of }\end{array}$ & 4.299 & 1.685 & -0.019 & 0.083 & 0.164 & 0.097 & 0.043 & 1 & & & \\
\hline 7 & $\begin{array}{l}\text { work experience } \\
\text { Entrepreneur owns another }\end{array}$ & 5.166 & 7.416 & 0.003 & 0.096 & -0.061 & 0.007 & 0.112 & -0.067 & 1 & & \\
\hline 8 & business & 0.170 & 0.375 & 0.041 & -0.084 & 0.041 & 0.081 & -0.071 & 0.051 & -0.044 & 1 & \\
\hline 9 & $\begin{array}{l}\text { Entrepreneur currently studies } \\
\text { Entrepreneur has a secondary }\end{array}$ & 0.452 & 0.498 & -0.142 & 0.025 & 0.038 & 0.035 & -0.043 & 0.068 & -0.033 & 0.015 & 1 \\
\hline 10 & job & 0.056 & 0.230 & -0.027 & -0.013 & -0.024 & 0.078 & 0.000 & 0.092 & -0.044 & -0.008 & 0.004 \\
\hline 11 & Entrepreneur's age & 42.390 & 11.754 & 0.053 & 0.055 & -0.124 & -0.182 & 0.013 & -0.266 & 0.196 & -0.006 & -0.014 \\
\hline 12 & Number of nonpaid workers & 0.275 & 0.731 & 0.047 & -0.111 & 0.026 & 0.006 & -0.042 & -0.126 & -0.057 & 0.028 & 0.030 \\
\hline 13 & Number if apprentices & 0.042 & 0.268 & 0.050 & 0.050 & 0.000 & -0.011 & 0.126 & -0.004 & 0.177 & -0.001 & -0.059 \\
\hline 14 & Number of temporary workers & 0.591 & 6.290 & 0.049 & -0.015 & 0.020 & -0.003 & -0.035 & -0.029 & -0.027 & 0.014 & -0.050 \\
\hline 15 & $\begin{array}{l}\text { Recruitment practices } \\
\text { Offers product/service }\end{array}$ & 0.536 & 0.499 & -0.022 & 0.087 & 0.072 & -0.052 & 0.246 & 0.080 & 0.047 & -0.035 & 0.001 \\
\hline 16 & guarantees & 0.708 & 0.455 & -0.038 & 0.080 & 0.099 & 0.076 & 0.107 & 0.074 & 0.033 & 0.032 & 0.137 \\
\hline 17 & Offers after-sales support & 0.197 & 0.398 & -0.028 & 0.094 & 0.129 & 0.125 & 0.079 & 0.176 & 0.081 & -0.014 & 0.008 \\
\hline 18 & Organizational age & 6.525 & 5.070 & 0.141 & -0.042 & -0.022 & -0.040 & 0.034 & -0.030 & 0.065 & 0.011 & -0.067 \\
\hline 19 & Organizational size & 3.604 & 5.912 & 0.001 & 0.101 & 0.253 & -0.022 & 0.075 & 0.237 & 0.012 & 0.028 & 0.043 \\
\hline 20 & $\begin{array}{l}\text { Consumer price index } \\
\text { Gross domestic product per }\end{array}$ & 17.087 & 2.293 & 0.094 & -0.054 & -0.296 & -0.024 & -0.172 & -0.181 & 0.001 & 0.002 & -0.276 \\
\hline 21 & capita & 6.781 & 2.069 & -0.116 & -0.094 & 0.260 & 0.074 & 0.132 & 0.159 & 0.021 & -0.003 & 0.438 \\
\hline 22 & Exports per capita & 394.384 & 219.484 & 0.003 & 0.779 & 0.041 & -0.103 & 0.082 & 0.039 & 0.026 & -0.008 & 0.012 \\
\hline 23 & Unemployment & 14.654 & 3.097 & -0.147 & 0.395 & 0.259 & -0.050 & 0.160 & 0.153 & 0.005 & -0.038 & 0.414 \\
\hline
\end{tabular}


TABLE 1 (continued)

Descriptive Statistics and Bivariate Correlations

\begin{tabular}{|c|c|c|c|c|c|c|c|c|c|c|c|c|c|}
\hline & 10 & 11 & 12 & 13 & 14 & 15 & 16 & 17 & 18 & 19 & 20 & 21 & 22 \\
\hline 10 & 1 & & & & & & & & & & & & \\
\hline 11 & -0.060 & 1 & & & & & & & & & & & \\
\hline 12 & -0.040 & 0.075 & 1 & & & & & & & & & & \\
\hline 13 & 0.014 & 0.036 & -0.025 & 1 & & & & & & & & & \\
\hline 14 & 0.001 & 0.009 & -0.018 & -0.004 & 1 & & & & & & & & \\
\hline 15 & 0.019 & -0.018 & 0.222 & 0.123 & -0.042 & 1 & & & & & & & \\
\hline 16 & -0.069 & -0.067 & -0.044 & 0.050 & 0.034 & 0.050 & 1 & & & & & & \\
\hline 17 & 0.045 & -0.019 & -0.065 & 0.029 & -0.007 & 0.030 & 0.126 & 1 & & & & & \\
\hline 18 & -0.047 & 0.299 & 0.030 & 0.081 & 0.011 & 0.006 & 0.020 & 0.104 & 1 & & & & \\
\hline 19 & 0.009 & 0.016 & 0.027 & 0.091 & 0.050 & 0.131 & 0.087 & 0.227 & 0.099 & 1 & & & \\
\hline 20 & 0.045 & 0.028 & 0.066 & -0.007 & 0.026 & -0.207 & -0.181 & -0.111 & 0.040 & -0.241 & 1 & & \\
\hline 21 & -0.029 & -0.010 & -0.027 & -0.016 & -0.041 & 0.205 & 0.159 & 0.114 & -0.053 & 0.220 & -0.860 & 1 & \\
\hline 22 & -0.026 & 0.012 & -0.073 & 0.034 & -0.047 & -0.007 & 0.059 & 0.091 & -0.037 & 0.031 & -0.017 & -0.206 & 1 \\
\hline 23 & -0.043 & -0.015 & -0.078 & -0.015 & -0.056 & 0.142 & 0.181 & 0.173 & -0.044 & 0.198 & -0.697 & 0.599 & 0.449 \\
\hline
\end{tabular}


TABLE 2

Discrete-time logistic regression of organizational survival

\begin{tabular}{|c|c|c|c|c|c|c|c|c|}
\hline Variables & Model 1 & Model 2 & Model 3 & Model 4 & Model 5 & Model 6 & Model 7 & Model 8 \\
\hline \multicolumn{9}{|l|}{ Independent variables } \\
\hline H1 Political and civil violence & & $\begin{array}{c}-0.204^{\star \star \star} \\
(0.066)\end{array}$ & $\begin{array}{c}-0.208^{\star \star \star} \\
(0.066)\end{array}$ & $\begin{array}{c}-0.166^{\star \star} \\
(0.069)\end{array}$ & $\begin{array}{c}-0.160 * \star \\
(0.068)\end{array}$ & $\begin{array}{c}-0.201^{\star \star \star} \\
(0.072)\end{array}$ & $\begin{array}{c}-0.195^{\star \star \star} \\
(0.073)\end{array}$ & $\begin{array}{c}-0.176^{\star \star} \\
(0.089)\end{array}$ \\
\hline H2 Incremental planning & & & $\begin{array}{l}-0.004 \\
(0.009)\end{array}$ & $\begin{array}{l}-0.005 \\
(0.009)\end{array}$ & $\begin{array}{l}-0.005 \\
(0.009)\end{array}$ & $\begin{array}{l}-0.002 \\
(0.009)\end{array}$ & $\begin{array}{l}-0.001 \\
(0.009)\end{array}$ & $\begin{array}{l}-0.001 \\
(0.009)\end{array}$ \\
\hline Comprehensive planning & & & & $\begin{array}{l}0.094^{* *} \\
(0.037)\end{array}$ & $\begin{array}{l}0.103^{\star \star} \\
(0.042)\end{array}$ & $\begin{array}{l}0.097^{\star *} \\
(0.042)\end{array}$ & $\begin{array}{l}0.096 * \star \\
(0.043)\end{array}$ & $\begin{array}{l}0.091^{\star *} \\
(0.045)\end{array}$ \\
\hline H3 Comprehensive planning squared & & & & & $\begin{array}{c}-0.070 \star * \\
(0.032)\end{array}$ & $\begin{array}{c}-0.072^{\star *} \\
(0.032)\end{array}$ & $\begin{array}{c}-0.065^{\star *} \\
(0.032)\end{array}$ & $\begin{array}{c}-0.068^{\star \star} \\
(0.033)\end{array}$ \\
\hline H4 Incremental planning X Political violence & & & & & & $\begin{array}{l}0.018^{\star *} \\
(0.009)\end{array}$ & $\begin{array}{l}0.021^{\star *} \\
(0.009)\end{array}$ & $\begin{array}{l}0.022^{\star *} \\
(0.009)\end{array}$ \\
\hline $\begin{array}{l}\text { H5 Comprehensive planning X Political } \\
\text { violence }\end{array}$ & & & & & & & $\begin{array}{l}-0.100 * * \\
(0.047)\end{array}$ & $\begin{array}{l}-0.106 * \star \\
(0.050)\end{array}$ \\
\hline $\begin{array}{l}\text { Comprehensive planning squared X Political } \\
\text { violence }\end{array}$ & & & & & & & & $\begin{array}{l}-0.027 \\
(0.073)\end{array}$ \\
\hline Entrepreneur variables & & & & & & & & \\
\hline Entrepreneur's gender (male) & $\begin{array}{l}-0.187^{* *} \\
(0.086)\end{array}$ & $\begin{array}{l}-0.129 \\
(0.088)\end{array}$ & $\begin{array}{l}-0.129 \\
(0.089)\end{array}$ & $\begin{array}{l}-0.115 \\
(0.089)\end{array}$ & $\begin{array}{l}-0.113 \\
(0.089)\end{array}$ & $\begin{array}{l}-0.108 \\
(0.089)\end{array}$ & $\begin{array}{l}-0.109 \\
(0.089)\end{array}$ & $\begin{array}{l}-0.109 \\
(0.089)\end{array}$ \\
\hline Entrepreneur's education level & $\begin{array}{c}0.013 \\
(0.026)\end{array}$ & $\begin{array}{c}0.018 \\
(0.026)\end{array}$ & $\begin{array}{c}0.019 \\
(0.026)\end{array}$ & $\begin{array}{c}0.014 \\
(0.026)\end{array}$ & $\begin{array}{c}0.013 \\
(0.026)\end{array}$ & $\begin{array}{c}0.015 \\
(0.026)\end{array}$ & $\begin{array}{c}0.013 \\
(0.026)\end{array}$ & $\begin{array}{c}0.013 \\
(0.026)\end{array}$ \\
\hline Entrepreneur's years of prior work experience & $\begin{array}{l}-0.002 \\
(0.005)\end{array}$ & $\begin{array}{c}0.000 \\
(0.005)\end{array}$ & $\begin{array}{c}0.000 \\
(0.005)\end{array}$ & $\begin{array}{c}-0.001 \\
(0.005)\end{array}$ & $\begin{array}{l}-0.000 \\
(0.005)\end{array}$ & $\begin{array}{c}-0.000 \\
(0.005)\end{array}$ & $\begin{array}{c}-0.001 \\
(0.005)\end{array}$ & $\begin{array}{c}-0.001 \\
(0.005)\end{array}$ \\
\hline Entrepreneur owns another business & $\begin{array}{c}0.123 \\
(0.104)\end{array}$ & $\begin{array}{c}0.097 \\
(0.104)\end{array}$ & $\begin{array}{c}0.098 \\
(0.104)\end{array}$ & $\begin{array}{c}0.091 \\
(0.105)\end{array}$ & $\begin{array}{c}0.085 \\
(0.104)\end{array}$ & $\begin{array}{c}0.088 \\
(0.105)\end{array}$ & $\begin{array}{c}0.091 \\
(0.105)\end{array}$ & $\begin{array}{c}0.092 \\
(0.105)\end{array}$ \\
\hline Entrepreneur currently studies & $\begin{array}{c}-0.242^{\star \star} \\
(0.096)\end{array}$ & $\begin{array}{c}-0.250 * \star \\
(0.097)\end{array}$ & $\begin{array}{c}-0.256^{\star \star *} \\
(0.098)\end{array}$ & $\begin{array}{c}-0.264^{\star \star *} \\
(0.102)\end{array}$ & $\begin{array}{c}-0.249 \star * \\
(0.098)\end{array}$ & $\begin{array}{c}-0.264^{\star \star *} \\
(0.099)\end{array}$ & $\begin{array}{c}-0.272^{\star \star *} \\
(0.099)\end{array}$ & $\begin{array}{c}-0.272^{\star \star *} \\
(0.099)\end{array}$ \\
\hline Entrepreneur has a secondary job & $\begin{array}{c}-0.138 \\
(0.177)\end{array}$ & $\begin{array}{c}-0.126 \\
(0.178)\end{array}$ & $\begin{array}{c}-0.128 \\
(0.179)\end{array}$ & $\begin{array}{c}-0.165 \\
(0.179)\end{array}$ & $\begin{array}{c}-0.167 \\
(0.179)\end{array}$ & $\begin{array}{c}-0.166 \\
(0.179)\end{array}$ & $\begin{array}{c}-0.164 \\
(0.179)\end{array}$ & $\begin{array}{c}-0.167 \\
(0.179)\end{array}$ \\
\hline Entrepreneur's age & $\begin{array}{c}0.001 \\
(0.004)\end{array}$ & $\begin{array}{c}0.002 \\
(0.004)\end{array}$ & $\begin{array}{c}0.002 \\
(0.004)\end{array}$ & $\begin{array}{c}0.003 \\
(0.004)\end{array}$ & $\begin{array}{c}0.003 \\
(0.004)\end{array}$ & $\begin{array}{c}0.003 \\
(0.004)\end{array}$ & $\begin{array}{c}0.003 \\
(0.004)\end{array}$ & $\begin{array}{c}0.003 \\
(0.004)\end{array}$ \\
\hline
\end{tabular}




\section{Organizational variables}

Number of nonpaid employees

\begin{tabular}{|c|c|c|c|c|c|c|c|}
\hline 0.052 & 0.035 & 0.035 & 0.036 & 0.028 & 0.023 & 0.027 & 0.029 \\
\hline (0.052) & (0.052) & $(0.052)$ & $(0.052)$ & $(0.052)$ & (0.052) & $(0.052)$ & (0.052) \\
\hline 0.273 & 0.239 & 0.238 & 0.238 & 0.252 & 0.255 & 0.242 & 0.243 \\
\hline (0.167) & (0.164) & $(0.164)$ & $(0.162)$ & $(0.162)$ & (0.161) & $(0.162)$ & $(0.162)$ \\
\hline 0.063 & 0.071 & 0.071 & 0.061 & 0.060 & 0.060 & 0.068 & 0.069 \\
\hline (0.043) & (0.045) & $(0.046)$ & $(0.045)$ & $(0.045)$ & $(0.044)$ & $(0.046)$ & $(0.047)$ \\
\hline-0.034 & -0.004 & -0.004 & 0.003 & -0.002 & -0.002 & -0.014 & -0.015 \\
\hline (0.086) & (0.087) & (0.087) & (0.088) & (0.087) & (0.087) & (0.088) & (0.088) \\
\hline-0.025 & 0.000 & 0.001 & -0.008 & -0.018 & -0.012 & -0.025 & -0.023 \\
\hline (0.089) & (0.090) & (0.090) & (0.090) & (0.090) & $(0.090)$ & (0.091) & (0.091) \\
\hline-0.109 & -0.106 & -0.106 & -0.138 & -0.135 & -0.135 & -0.142 & -0.142 \\
\hline (0.107) & (0.107) & (0.108) & (0.109) & (0.108) & (0.108) & (0.109) & (0.109) \\
\hline $0.038^{* * *}$ & $0.039 * * *$ & $0.039 * * *$ & $0.039 * * \star$ & $0.038^{\star \star *}$ & $0.039 * \star \star$ & $0.040 * \star \star$ & $0.040^{* * *}$ \\
\hline (0.008) & (0.008) & (0.008) & (0.008) & (0.008) & (0.008) & (0.008) & (0.008) \\
\hline-0.001 & 0.001 & 0.002 & 0.003 & 0.002 & 0.002 & 0.003 & 0.003 \\
\hline (0.009) & (0.008) & (0.009) & (0.009) & (0.009) & (0.009) & (0.009) & (0.009) \\
\hline Yes & Yes & Yes & Yes & Yes & Yes & Yes & Yes \\
\hline-0.019 & -0.004 & -0.004 & -0.009 & -0.006 & -0.004 & -0.010 & -0.011 \\
\hline$(0.041)$ & $(0.041)$ & $(0.041)$ & $(0.041)$ & $(0.041)$ & $(0.041)$ & $(0.042)$ & $(0.042)$ \\
\hline 0.090 & 0.126 & 0.133 & 0.094 & 0.099 & 0.112 & 0.084 & 0.082 \\
\hline (0.147) & $(0.146)$ & (0.146) & (0.148) & $(0.147)$ & (0.148) & (0.148) & (0.149) \\
\hline $0.001^{* * *}$ & $0.001^{\star \star *}$ & $0.001^{* * *}$ & $0.001 * \star \star$ & $0.001^{* * *}$ & $0.001^{\star \star *}$ & $0.001^{\star \star \star}$ & $0.001^{* * *}$ \\
\hline$(0.000)$ & $(0.000)$ & $(0.000)$ & $(0.000)$ & $(0.000)$ & $(0.000)$ & $(0.000)$ & $(0.000)$ \\
\hline$-0.091^{\star \star \star}$ & $-0.086^{\star \star \star}$ & $-0.085^{\star * *}$ & $-0.079 * \star \star *$ & $-0.083^{* * *}$ & $-0.083^{\star \star \star}$ & $-0.084^{\star \star \star}$ & $-0.084^{\star \star \star}$ \\
\hline$(0.027)$ & $(0.026)$ & $(0.026)$ & $(0.026)$ & $(0.026)$ & $(0.026)$ & $(0.026)$ & $(0.026)$ \\
\hline 1.059 & 0.338 & 0.321 & 0.302 & 0.397 & 0.304 & 0.495 & 0.520 \\
\hline (0.889) & $(0.902)$ & $(0.904)$ & (0.907) & $(0.906)$ & (0.909) & (0.913) & (0.915) \\
\hline 83.60 *** & $92.02^{\star \star *}$ & $91.76^{\star \star *}$ & $78.94^{\star \star *}$ & 100.80 *** & $104.18^{\star \star \star}$ & 108.50 *** & $108.56^{\star \star *}$ \\
\hline
\end{tabular}

Number of apprentices

Number of temporary employees

Recruitment practices

Offers product/service guarantees

Offers after-sales support

Organizational age

Organizational size

Industry controls

\section{Environmental variables}

Regional consumer price index

Regional gross domestic product per capita

Regional exports per capita

Regional unemployment

\section{Constant}

Wald chi squared

83.60***

$92.02^{\star \star \star}$

Standard errors in parentheses

* significant at 10\%; ** significant at 5\%; ** significant at $1 \%$ 
Figure 1

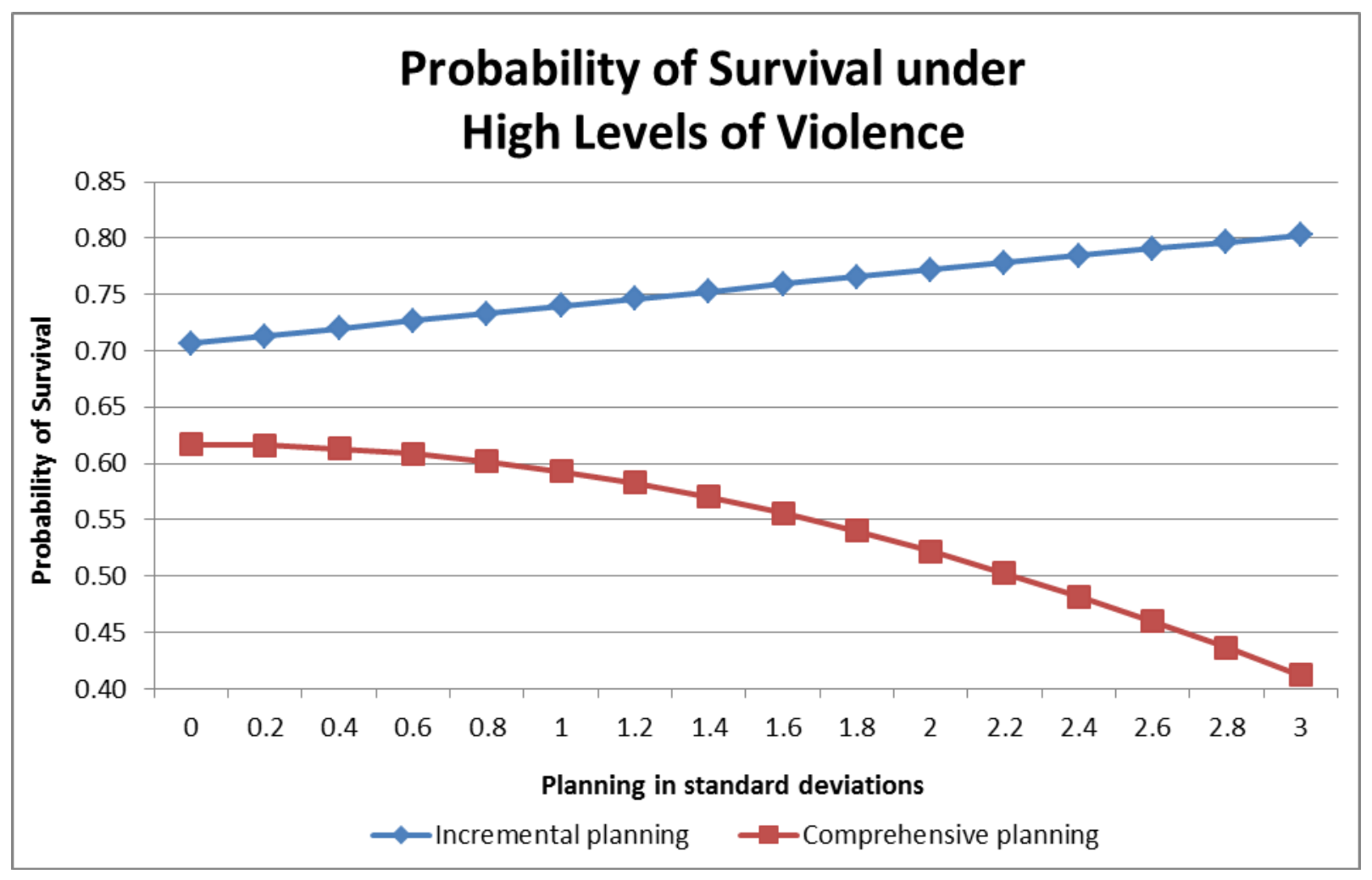

